\title{
Free-living marine nematodes actively choose habitat when descending from the water column
}

\author{
Jörgen Ullberg*, Emil Ólafsson
}

Department of Zoology, University of Stockholm, 10691 Stockholm, Sweden

\begin{abstract}
Benthic organisms living in shallow high-energy areas are regularly suspended into the water column, where they dwell for longer or shorter periods before they re-enter the benthos. Marine free-living nematodes, normally the most abundant metazoans in soft sediments, lack a pelagic larval stage and are exceedingly poor swimmers. Although empirical data are lacking, nematodes are regularly considered to settle as passive particles through the water column. We carried out an experiment to assess whether nematodes are able to choose settling spots when descending from the water column. In the laboratory, nematodes were extracted from sediment collected from a shallow sandy bay and allowed to settle in a water column of $1 \mathrm{~m}$ to the bottom, which was seeded with 4 small containers containing: nothing, sediment without organic matter, sediment with added pelagic algae and sediment with added benthic algae (BA). The nematodes showed a clear preference for the BA containers, being about 7 times as abundant there than in the other treatments $(\mathrm{p}<0.001)$. The nematode composition was different among treatments with 3 abundant species more or less confined to BA. The size distribution of the nematodes shows that the smallest nematodes are also the most efficient in choosing habitat. This is in concordance with the prediction that swimming ability is coupled to nematode size and water viscosity. The results obtained show that the conception of nematodes as passive particles in the water column is not entirely valid.
\end{abstract}

KEY WORDS: Nematodes $\cdot$ Settling $\cdot$ Suspension $\cdot$ Food choice

\section{INTRODUCTION}

Benthic and dermersal marine organisms are often encountered in the pelagic zone, particularly as larvae. Indeed, the majority of macrobenthic invertebrate species possess pelagic larval stages, which may play an important role in their dispersal. Marine, free-living nematodes, normally the most abundant and species rich of all sediment-dwelling metazoans, do not have a pelagic larval stage to facilitate dispersal (Chandler \& Fleeger 1983) and are poor swimmers (e.g. Palmer 1984). They are, however, often encountered in the water column, especially in high-energy areas, where wave or tidal actions induce their suspension (Palmer 1983, Fegley 1985, Bertelsen 1997, Powers 1998). Such dislodgement can be important for less-mobile taxa to achieve dispersal (Powers 1998), and quite large proportions of the total populations can be affected, for example, Fegley (1985) found that up to $10 \%$ of the total nematode populations could be suspended and dispersed during a single tidal cycle. Once suspended, the organisms can be transported at rates close to the water velocity (Bertelsen 1997); mean water velocity and its variation with height above the bed dictate most of the distances traversed (Harvey \& Vincent 1977). The importance of suspension for dispersal in marine nematodes is perhaps best exemplified by their quick colonization of azoic sediments in high-energy areas such as intertidal mudflats (Kern \& Taghon 1986, Billheimer \& Coull 1988, Savidge \& Taghon 1988, Atilla \& Fleeger 2000, Zhou 2001), where ambient density levels may be reached within 1 tidal cycle. On the other hand, in the subtidal zone, where currents are not strong enough to suspend nematodes in the water column, recolonisation into azoic sediments is much slower (Thistle 1980, Alongi et al. 1983, Chandler \& 
Fleeger 1983, Sherman et al. 1983, Widbom 1983, Ólafsson \& Moore 1990). It also seems that the process in intertidal areas is mostly dominated by passive movement of nematodes, as species compositions in the water column and the bottom have been noted to be very similar (Bell \& Sherman 1980, Commito \& Tita 2002). In subtidal areas, active movement of nematodes may be much more important, as species composition in colonized areas has been found to be different from that in background areas (Alongi et al. 1983, Ólafsson \& Moore 1992).

There are several factors controlling the presence and abundance of nematodes in the water column: some are morphological, some behavioural and some physiological. Morphological adaptations in nematodes having to cope with life in exposed sandy habitats have been found to be long setae and large body sizes, which offer resistance to dislodgment from the sediment (Warwick 1971, Tietjen 1976). Another adaptation in nematodes is a long, slender tail (Thistle \& Sherman 1985). Behavioural strategies in response to exposure to advection by currents and/or waves are 2 -fold. Firstly, there are nematodes that burrow deeper down into the sediments to evade suspension as they encounter increased flow (Fegley 1987). Secondly, there are nematodes that actively leave the sediment to be advected (Chandrasekara \& Frid 1996). Physiological adaptations can consist of sticky secretions which are produced by glands, especially the caudal glands, and adhere to the sediment grains (Gerlach 1948, 1957, Riemann 1988).

Researchers have found an array of environmental cues that pelagic larvae of macrofauna and fish use to select habitat for settling (Bologna \& Heck 2000, Krug \& Zimmer 2000b, Olivier et al. 2000). However, the question remains of whether nematodes are able to choose where to settle after sojourning in the water column. Marine nematodes often display spatial aggregations in their distribution (Hogue 1982, Heip et al. 1985, Austen et al. 1989, Ólafsson 1992), a phenomenon that might be coupled to their feeding practices (Lee et al. 1977, Tietjen \& Lee 1977, Hogue \& Miller 1981). At least 2 criteria must be fulfilled to permit selective settling by nematodes: they must have receptors allowing them to discern attractive spots, and they must be able to influence where they settle on the bottom. Up until now, as far as we are aware, only 1 study has addressed settling behaviour of marine free-living nematodes under controlled, manipulative laboratory situations. Bertelsen (1997) investigated the settling behaviour of 3 species; he found that body shape can have a profound effect on the settling rate and that nematodes settle at a higher rate in still water than in a flume. He also found that one of the species did alter its settling speed depending on sediment type, with a higher settling rate occurring over attractive sediment than over unattractive sediment, and that in the flume it settled much sooner over attractive than over unattractive sediment.

In this study we carried out an experiment with the main aim of seeing whether nematodes are able to influence their own settlement after being brought into the water column. We tested specifically the following hypotheses:

H1: Nematodes prefer to settle in spots containing sediment than in spots free from sediment.

H2: Nematodes actively settle in spots where natural food resources are present.

H3: Settling choice is species specific, i.e. some species are better at locating attractive spots than others.

\section{MATERIALS AND METHODS}

Sand was collected in Sandviken, a small sandy bay at Askö, in the Trosa archipelago, Baltic Sea Proper $\left(58^{\circ} 49^{\prime} \mathrm{N}, 17^{\circ} 38^{\prime} \mathrm{E}\right)$. The uppermost $5 \mathrm{~cm}$ were collected and brought back to the laboratory, where the sand was sieved using a $1.0 \mathrm{~mm}$ mesh. To assess the amount of organic material in the sediment, sediment was first dried in a heating cabinet to render it completely dry. It was weighed and afterwards burned at $505^{\circ} \mathrm{C}$ for $4 \mathrm{~h}$ to obtain the ash free dry weight of the sediment. The same procedure was also used to estimate the amount of organic carbon in spring bloom and benthic algae material. Prior to use, the sand was homogenised to avoid any sorting artefacts.

To extract the sediment for organisms, the uppermost 2 to $3 \mathrm{~cm}$ was collected at Sandviken and placed in a settling chamber, which comprised a plastic cylinder (Fig. 1). The cylinder was filled to just beneath the

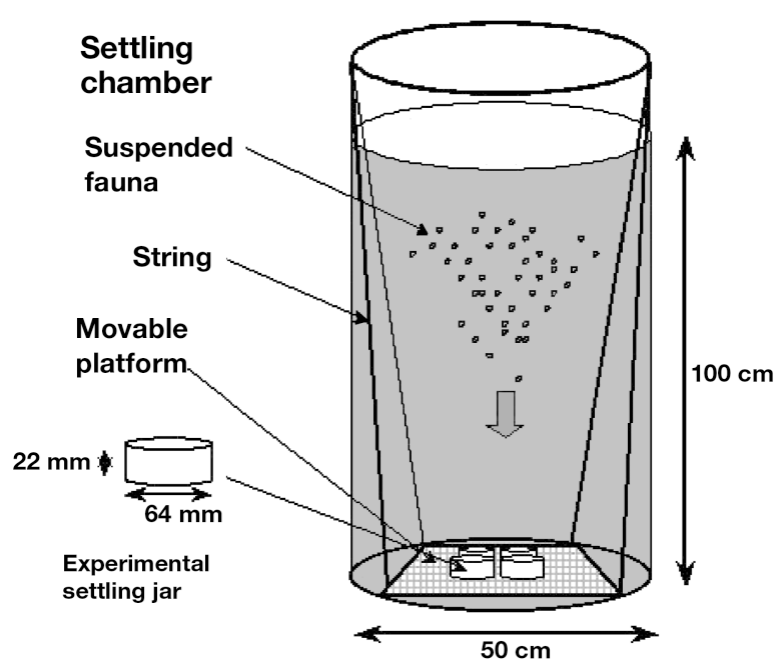

Fig. 1. Diagram of the experimental setup 
rim with sand-filtered, natural sea water from a depth of $15 \mathrm{~m}$. The contents of the container were vigorously stirred with an aluminium rod to resuspend the sediment and organisms. Most of the solid and heavier material was allowed to settle before approximately 701 (about 1/3 the volume of the cylinder) of water was siphoned off through a $40 \mu \mathrm{m}$ sieve. The procedure was repeated several times, and the screen residues were gently rinsed into a bucket pending division into separate experimental runs.

A total of approximately 85000 nematodes were extracted, allowing approximately 8500 individuals per run when the organisms were divided into 10 equal parts.

In the settling experiment, we used a plastic cylinder with an internal diameter of $50 \mathrm{~cm}$ and a $200 \mathrm{l}$ capacity (Fig. 1). The total area of the cylinder bottom was approximately $1964 \mathrm{~cm}^{2}$. The settling distance from the surface, where the nematodes were added to the bottom was approximately $100 \mathrm{~cm}$.

For each experimental run, 4 plastic settling containers (internal diameter of $64 \mathrm{~mm}$ and height $22 \mathrm{~mm}$ [60 ml]; area of approximately $32 \mathrm{~cm}^{2}$ ) were used, 1 each of 2 algae treatments (benthic algae and pelagic spring bloom material) and 2 different controls (azoic sediment and totally empty). The 2 algae treatments contained azoic sand and carbon field levels of benthic organic material: diatom aggregations (mainly Amphipleura rutilans) collected at the sediment surface from the field station or pelagic spring bloom material (a mixture of diatoms including mainly Skeletonema costatum, and Thalossosira sp.) collected with a plankton net $2 \mathrm{~km}$ offshore during spring. The algal material was immediately frozen $\left(-20^{\circ} \mathrm{C}\right)$ upon retrieval. Prior to adding the algal material to the inorganic sand, it was first thawed and then repeatedly pressed through a $100 \mu \mathrm{m}$ sieve to eliminate any meiofauna. Natural field levels of carbon, $5 \times 10^{-3} \mathrm{~g} \mathrm{C}$ $\mathrm{ml}^{-2}$, were added to $50 \mathrm{~g}$ inorganic sand and thoroughly mixed into the settling jars of both algae treatments. The control jars were either filled with $50 \mathrm{~g}$ inorganic sand or kept empty.

Prior to each run, the settling containers were placed in a weighted plastic tray. The tray was perforated, allowing water to run off upon retrieval (Fig. 1). The tray barely fitted into the cylinder, solving the problem of centralizing the tray in the container prior to each run. The settling containers were placed centrally and equidistant from each other (approximately $3 \mathrm{~cm}$ edge to edge) in the tray and thereby also equidistant from the cylinder wall. Prior to lowering the tray, the sample containers were topped off with seawater to prevent water rushing over the rim and disturbing the contents during submersion. Strings were attached to each corner of the tray, facilitating the lowering to and retrieval from the bottom of the cylinder of the tray in a horizontal orientation.

At the beginning of each run, the plastic cylinder was filled with $200 \mathrm{l}$ of seawater, and about $10 \mathrm{~min}$ later the tray containing the settling containers was submerged and placed on the bottom. The nematodes were evenly spread out over the whole water surface in the cylinder. With the tray and nematodes in place, the cylinder was left for $2 \mathrm{~h}$ and then a hose $(18 \mathrm{~mm}$ inner diameter) was used to siphon off $1501(3 / 4$ of the total water mass) through a $40 \mu \mathrm{m}$ sieve. The residue was transferred into a plastic vial with $4 \%$ formalin to check how many organisms remained in the water column. The tray was retrieved and the contents of the settling containers were transferred into formalin (4\% final conc.). Between runs the cylinder and tray were thoroughly rinsed with filtered seawater.

Sample handling. To extract the fauna from the sediment, each sample was transferred to a 11 glass jar, which was filled to approximately $750 \mathrm{ml}$. The contents were vigorously stirred, and after a brief period, when the heavier particles had settled out, the supernatant was sieved through a $40 \mu \mathrm{m}$ screen. This procedure was repeated 4 times. The samples were enumerated under a dissecting microscope at $25 \times$ magnification to the highest taxa. The samples without sediment were directly transferred to the $40 \mu \mathrm{m}$ screen and subsequently enumerated.

The source samples ( 2 pooled $20 \mathrm{ml}$ subsamples) used to evaluate the species composition of the nematodes added to each run were directly transferred to a $40 \mu \mathrm{m}$ screen, and treated thereafter like the other samples.

For genus identification, nematodes were selected under a dissecting microscope and transferred into mounting liquid (5\% pure [95\%] ethanol, $5 \%$ glycerol, and $90 \%$ Milli-Q filtered water); the samples were left on a heating plate at $50^{\circ} \mathrm{C}$, leading to the evaporation of the ethanol and water and leaving the nematodes impregnated with pure glycerol. Specimens were later transferred to slides, and the 100 first identifiable nematodes (if so many were available) were identified to at least genus level. To lessen the risk of biased size selection of nematodes, all nematodes were selected from randomly predefined areas of a Petri dish.

Size determination. The volumetric method of Feller \& Warwick (1988) was used to assess the dry weight of the nematodes. The length contours of the nematodes were digitized using a Hamamatsu 3CCD video camera, model C5810, and a picture capturing system (Leica, Quantimet 500IW) with an integrated software system that automatically calculated the length in $\mu \mathrm{m}$.

Statistics. Numerical differences in settling density of total nematode numbers between treatments was 
assessed with Welch's test (Welch 1947) for averages of 5 experimental runs, as the assumption for equal variances could not be met for a parametric test. This was followed by Scheffé's (1953) test to evaluate which treatments were significantly different from each other. The above tests were executed using JMP statistical software (SAS Institute). A 1-way ANOVA was used to test differences in species abundance size estimates among benthic algae treatments, for 3 experimental runs. Genus abundance data were doublesquare-root transformed and subjected to non-metric multidimensional scaling ordination (MDS) and cluster analysis using the Bray-Curtis similarity measure. The ANOSIM randomisation test (Clarke \& Green 1988) was used to test for significant differences in nematode community structure, and the dissimilarity percentage program (SIMPER; Clarke 1993) was used to identify the genera making the greatest contribution to differences between clusters observed in the MDS plot. All multivariate tests were done using the multivariate statistical software package Primer 5.1 developed at the Plymouth Marine Laboratory, UK.

Table 1. Nematodes in the water column and in 4 different settlement pots (mean and SD of 3 experiments). BA: benthic algae; PA: pelagic algae; CS: control with sand; C-S: control without sand; \%: percentage of initial numbers in the water column; -: not measured

\begin{tabular}{|c|c|c|c|c|c|c|c|c|c|c|c|c|c|c|}
\hline \multirow{3}{*}{$\begin{array}{l}\text { Taxon } \\
\text { Adoncholaimus }\end{array}$} & \multirow{3}{*}{$\begin{array}{c}\text { Weight } \\
(\mu g)\end{array}$} & \multicolumn{5}{|c|}{ In the water column } & \multicolumn{6}{|c|}{ - In the treatments after $2 \mathrm{~h}$} & \multirow{2}{*}{\multicolumn{2}{|c|}{$\begin{array}{c}\mathrm{C}-\mathrm{S} \\
\mathrm{Avg} \pm \mathrm{SD}\end{array}$}} \\
\hline & & \multicolumn{2}{|c|}{$\begin{array}{c}\text { Initial } \\
\text { Avg } \pm \text { SD }\end{array}$} & \multicolumn{2}{|c|}{$\begin{array}{l}\text { After } 21 \\
\text { Avg } \pm \text { SD }\end{array}$} & \multirow{2}{*}{$\%$} & \multicolumn{2}{|c|}{$\begin{array}{c}\mathrm{BA} \\
\operatorname{Avg} \pm \mathrm{SD}\end{array}$} & \multicolumn{2}{|c|}{$\begin{array}{c}\mathrm{PA} \\
\operatorname{Avg} \pm \mathrm{SD}\end{array}$} & \multicolumn{2}{|c|}{$\begin{array}{c}\mathrm{CS} \\
\operatorname{Avg} \pm \mathrm{SD}\end{array}$} & & \\
\hline & & 80 & 74 & 0 & 0 & & 1 & 1 & 0 & 1 & 0 & 1 & 0 & 1 \\
\hline Anoplostoma & 0.240 & 1656 & 527 & 37 & 9 & 2 & 10 & 7 & 12 & 5 & 10 & 5 & 15 & 2 \\
\hline Apodontium & 0.171 & 0 & 0 & 0 & 0 & & 0 & 0 & 0 & 0 & 0 & 1 & 0 & 1 \\
\hline Ascolaimus & 0.130 & 0 & 0 & 0 & 0 & & 2 & 4 & 0 & 0 & 0 & 0 & 0 & 0 \\
\hline Axonolaimus & 0.170 & 53 & 47 & 1 & 1 & 1 & 2 & 4 & 1 & 1 & 3 & 2 & 2 & 1 \\
\hline Bathylaimus & 0.310 & 0 & 0 & 0 & 0 & & 0 & 0 & 0 & 0 & 1 & 1 & 0 & 0 \\
\hline Calomicrolaimus & 0.029 & 0 & 0 & 8 & 8 & & 4 & 8 & 0 & 1 & 0 & 0 & 1 & 1 \\
\hline Campylaimus & - & 0 & 0 & 1 & 2 & & 0 & 0 & 0 & 0 & 0 & 0 & 0 & \\
\hline Chromadorita & 0.096 & 445 & 161 & 41 & 22 & 9 & 151 & 51 & 7 & 4 & 4 & 1 & 3 & 1 \\
\hline Cobbia & 0.037 & 0 & 0 & 3 & 6 & & 127 & 67 & 0 & 0 & 1 & 2 & 1 & 2 \\
\hline Daptonema & 0.197 & 976 & 620 & 36 & 18 & 4 & 12 & 6 & 4 & 4 & 9 & 1 & 12 & 2 \\
\hline Desmolaimus & 0.241 & 276 & 82 & 22 & 8 & 8 & 2 & 4 & 3 & 1 & 3 & 2 & 2 & 2 \\
\hline Dichromadora & 0.166 & 240 & 222 & 19 & 7 & 8 & 0 & 0 & 5 & 4 & 2 & 2 & 3 & 2 \\
\hline Diplolaimella & - & 24 & 42 & 0 & 0 & 0 & 0 & 0 & 0 & 0 & 0 & 0 & 0 & 0 \\
\hline Dorylaimus & - & 24 & 42 & 0 & 0 & 0 & 0 & 0 & 0 & 0 & 0 & 0 & 0 & 0 \\
\hline Enoplolaimus & 0.266 & 88 & 152 & 10 & 5 & 11 & 0 & 0 & 1 & 1 & 2 & 2 & 1 & 2 \\
\hline Halanonchus & - & 0 & 0 & 1 & 1 & & 0 & 0 & 0 & 0 & 0 & 0 & 0 & 0 \\
\hline Halalaimus & 0.042 & 53 & 47 & 2 & 4 & 4 & 0 & 0 & 0 & 0 & 0 & 1 & 0 & 0 \\
\hline $\begin{array}{l}\text { Hypodontolaimus } \\
\text { balticus }\end{array}$ & 0.487 & 746 & 161 & 8 & 3 & 1 & 2 & 3 & 6 & 2 & 6 & 1 & 7 & 2 \\
\hline Innocuonema & - & 0 & 0 & 1 & 1 & & 0 & 0 & 0 & 0 & 0 & 0 & 0 & 0 \\
\hline Leptolaimoides & - & 0 & 0 & 1 & 1 & & 0 & 0 & 0 & 0 & 0 & 0 & 0 & 0 \\
\hline Leptolaimus & 0.025 & 29 & 51 & 3 & 3 & 10 & 9 & 16 & 0 & 0 & 0 & 0 & 0 & 0 \\
\hline Linhomoeidae genus & 0.231 & 0 & 0 & 0 & 0 & & 0 & 0 & 1 & 1 & 0 & 0 & 0 & 0 \\
\hline Metadesmolaimus & 0.165 & 112 & 136 & 2 & 2 & 2 & 11 & 19 & 0 & 1 & 0 & 1 & 0 & 0 \\
\hline Meyersia & 0.270 & 0 & 0 & 1 & 2 & & 0 & 0 & 1 & 1 & 0 & 1 & 1 & 1 \\
\hline Microlaimus & 0.024 & 0 & 0 & 7 & 7 & & 77 & 41 & 0 & 0 & 0 & 0 & 1 & 2 \\
\hline Monhystera & 0.167 & 128 & 148 & 8 & 4 & 6 & 6 & 6 & 2 & 1 & 1 & 1 & 4 & 5 \\
\hline Oncholaimus & - & 31 & 54 & 0 & 0 & 0 & 0 & 0 & 0 & 0 & 0 & 0 & 0 & 0 \\
\hline Paracanthonchus & 0.217 & 1860 & 142 & 74 & 12 & 4 & 17 & 18 & 16 & 1 & 19 & 10 & 17 & 7 \\
\hline Paracyatholaimus & - & 0 & 0 & 2 & 2 & & 0 & 0 & 0 & 0 & 0 & 0 & 0 & 0 \\
\hline Paradontophora & 0.065 & 0 & 0 & 0 & 0 & & 0 & 0 & 0 & 0 & 0 & 1 & 0 & 0 \\
\hline Paramonhystera & - & 0 & 0 & 1 & 1 & & 0 & 0 & 0 & 0 & 0 & 0 & 0 & 0 \\
\hline Prochromadora & - & 29 & 51 & 1 & 2 & 5 & 0 & 0 & 0 & 0 & 0 & 0 & 0 & 0 \\
\hline Promonhystera & 0.095 & 0 & 0 & 0 & 0 & & 0 & 0 & 0 & 1 & 0 & 1 & 0 & 0 \\
\hline Sphaerolaimus & 1.500 & 73 & 126 & 1 & 2 & 1 & 0 & 0 & 0 & 1 & 1 & 1 & 1 & 1 \\
\hline Steineria & - & 58 & 101 & 0 & 0 & 0 & 0 & 0 & 0 & 0 & 0 & 0 & 0 & 0 \\
\hline Syndontia & - & 31 & 54 & 0 & 0 & 0 & 0 & 0 & 0 & 0 & 0 & 0 & 0 & 0 \\
\hline Theristus & 0.102 & 313 & 113 & 19 & 10 & 6 & 57 & 28 & 1 & 1 & 4 & 1 & 3 & 2 \\
\hline Trichotheristus & 0.608 & 377 & 342 & 7 & 4 & 2 & 0 & 0 & 3 & 1 & 2 & 1 & 5 & 0 \\
\hline Viscosia & 0.354 & 312 & 149 & 6 & 3 & 2 & 0 & 0 & 1 & 1 & 1 & 1 & 0 & 0 \\
\hline Unknown & - & 461 & 294 & 23 & 11 & 5 & 25 & 43 & 0 & 0 & 2 & 2 & 3 & 3 \\
\hline
\end{tabular}




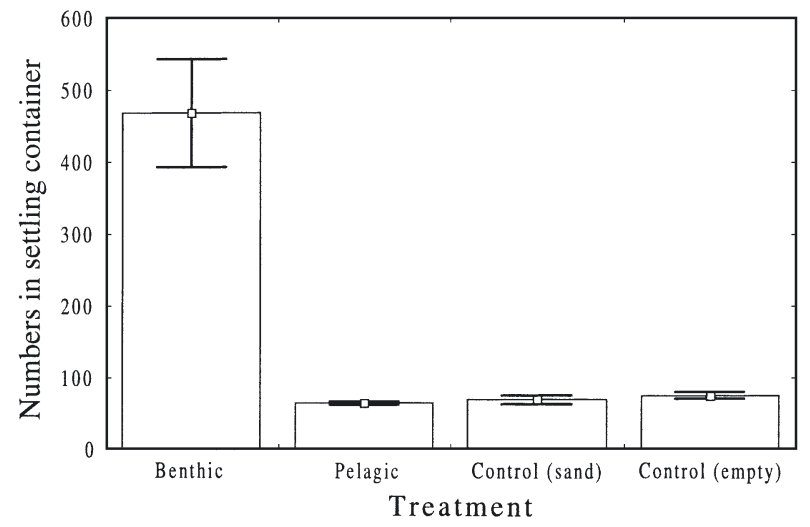

Fig. 2. Average numbers $(n=5)$ with standard error bars of the nematodes in the settling containers of the different treatments

\section{RESULTS}

There was a large significant $(p<0.01)$ difference in the number of nematodes in the settling containers. Containers seeded with benthic algae had about 7 times more nematodes than the other containers, which had similar numbers (Scheffé test, p $<0.001$; Fig. 2). Assuming that nematodes settled at the same speed to the bottom of the cylinder as in the empty control, then about $70 \%$ had reached the bottom within the $2 \mathrm{~h}$. In the top $3 / 4$ of the water column, only $4 \%$ of the nematodes added were retrieved, leaving about $25 \%$ in the remaining water, i.e. $25 \mathrm{~cm}$ above the bottom.

Altogether 40 nematode genera/species were found in the samples (Table 1). Both the cluster analysis and the MDS ordination showed the same groupings of samples, i.e. the source samples (S), the samples in the water column after $2 \mathrm{~h}$ (W) and the benthic algae treatment (B) all formed separate groups while the rest of the treatments formed a group of their own $(\mathrm{P}, \mathrm{E}, \mathrm{C}$; Fig. 3). There was an overall significant difference among the groups (ANOSIM global $\mathrm{R}<0.001$ ) and between all pairs apart from $B$ and $\mathrm{S}$ in pair-wise comparisons (ANOSIM, $\mathrm{p}<0.005$ ). The SIMPER analysis indicated that 6 genera accounted mostly for this grouping (Table 2). Dissimilarity between groups was in general high, ranging from 66 to $98 \%$ (Table 2). Of the 20 most abundant genera in the settling containers, 5 were not recorded in the source samples (Table 1). Two of these, Cobbia and Microlaimus, were the second and third most abundant genera in the benthic samples respectively, while the others were found in much lower numbers (Table 1). Of the 10 most abundant genera in the source samples, 2 (Chromadorita and Theristus) showed preference for the benthic algae treatment (ANOVA, p $<0.001$; Table 1), while
Table 2. SIMPER analysis showing genera ranked according to average Bray-Curtis dissimilarity between groups. The list of genera was limited to a cumulative percentage dissimilarity of $50 \%$, i.e. when $50 \%$ of the dissimilarity was reached, remaining genera were skipped. Percentages in parentheses are dissimilarities between groups. B: benthic algae; S: source samples; W: water-column samples; O: pooled other treatments

\begin{tabular}{|llcc|}
\hline Group & Genus & $\%$ & Cum \% \\
\hline B vs O (85\%) & Chromadorita & 32 & 32 \\
& Cobbia & 26 & 57 \\
B vs S (94\%) & Paracanthonchus & 24 & 24 \\
& Anoplostoma & 21 & 44 \\
& Daptonema & 12 & 56 \\
O vs S (98\%) & Paracanthonchus & 24 & 24 \\
& Anoplostoma & 21 & 44 \\
B vs W (70\%) & Daptonema & 12 & 56 \\
& Cobbia & 21 & 21 \\
& Chromadorita & 19 & 40 \\
O vs W (66\%) & Microlaimus & 12 & 52 \\
& Paracanthonchus & 23 & 23 \\
& Chromadorita & 14 & 37 \\
& Daptonema & 10 & 47 \\
S vs W $(93 \%)$ & Anoplostoma & 10 & 57 \\
& Paracanthonchus & 24 & 24 \\
& Anoplostoma & 21 & 44 \\
& Daptonema & 12 & 56 \\
\hline
\end{tabular}
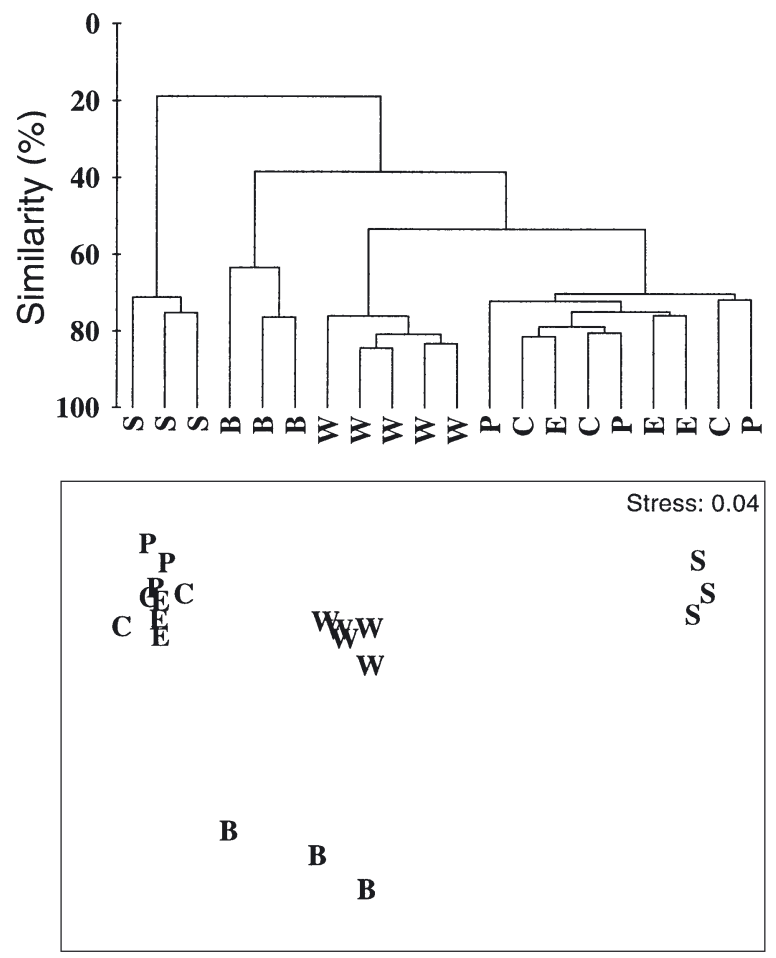

Fig. 3. Hierarchical cluster analysis (top) and non-metric multidimensional scaling ordination (bottom) analyses on fourth-root-transformed nematode genera abundance data using the Bray-Curtis similarity index. B: benthic algae; P: pelagic algae; C: control (sand); E: control (empty); S: source samples; W: water-column samples 
Table 3. Width, length and estimated weight (mean $\pm \mathrm{SD}$ ) of the nematodes identified from the settling jars. BA: benthic algae; PA: pelagic algae; CS: control with sand; C-S: control without sand

\begin{tabular}{|lcccc|}
\hline & BA $(\mathrm{n}=292)$ & PA $(\mathrm{n}=160)$ & CS $(\mathrm{n}=188)$ & C-S $(\mathrm{n}=206)$ \\
\hline Width $(\mu \mathrm{m})$ & $24 \pm 10$ & $40 \pm 15$ & $36 \pm 14$ & $36 \pm 13$ \\
Length $(\mu \mathrm{m})$ & $558 \pm 280$ & $944 \pm 315$ & $877 \pm 325$ & $915 \pm 316$ \\
Weight $(\mu \mathrm{g})$ & $0.081 \pm 0.153$ & $0.296 \pm 0.352$ & $0.238 \pm 0.301$ & $0.246 \pm 0.318$ \\
\hline
\end{tabular}

the rest were found in similar numbers in all treatments, including Daptonema and Hypodontolaimus, among the most abundant genera in the source samples (Table 1). Genera represented by small individuals (ca. $<0.1 \mu \mathrm{g}$ ) showed a clear preference for the benthic algae treatment, while genera represented by larger individuals, in general, showed no distinct choice of habitat. One exception was individuals belonging to the genus Trichotheristus that did not settle in the benthic algae treatment, but in all other treatments, albeit in low numbers (Table 1). On the whole, nematodes in the benthic algae treatment were significantly shorter, thinner and lighter than nematodes in the other treatments (Table 3; ANOVA, p < 0.001).

\section{DISCUSSION}

In contrast to the general belief (e.g. Palmer 1983, 1984, Powers 1998), the results of our experiment strongly suggest that settling of marine, free-living, benthic nematodes is not entirely a random or passive process. In our experiment several species belonging to different genera and families were clearly able to choose settling points, and they became so abundant in one of the treatments that changes in assemblage structure among the settling jars were evident. We believe that they must do so by active swimming. While benthic nematodes are notoriously poor swimmers (e.g. Palmer 1984), swimming has been observed in phytal nematodes (Jensen 1981) and in nematodes in other habitats (Peters 1928). Those species that displayed active choice were all, but for one, small. These findings are in concordance with the findings of Crofton (1966), who stated that only the smallest nematodes will be able to swim freely in water, because, for larger nematodes, the viscosity will be insufficient for the sinusoidal wave propagation that nematodes utilize for swimming (Crofton 1966). However, in our results we found an exception to this view, as the large Trichotheristus sp. never settled in the benthic algae treatment. Contrary to earlier beliefs, Trichotheristus sp., a large nematode with very long and conspicuous setae all along its body length, seems able to swim. It was the third heaviest nematode of the genera we encountered. However, it is known that not only the viscosity influences the nematodes ability to swim. A nematode must produce enough propulsive power to sufficiently exceed the downward force of its own weight (Wallace \& Doncaster 1964). To be able to actively swim upward in liquids, a nematode must have a length $\mathrm{x}$ wave frequency (LF) of more than 100. However, if nematodes have a LF between 20 and 80, they are able to leave the sediments and enter the water column (Wallace \& Doncaster 1964). So it seems that viscosity, sinking speed and high wave frequencies are decisive elements in nematode swimming. The very long setae that Trichotheristus sp. has along the length of its body may act as sea anchors, thereby increasing the drag force on the nematode and retarding settling. However, this is unlikely because of the very few numbers recorded in the water column after $2 \mathrm{~h}$. Alternative explanations are that it uses its setae as oars, or simply that they were present in the benthic algae treatment but consistently were not taken in the sub-samples, i.e. $1 / 5$ of the original sample, because of their low numbers.

We believe that the nematodes used chemotaxis as guidance to the preferred treatment, as evidenced in parasitic and terrestrial nematodes as well as other marine organisms (Wallace \& Doncaster 1964, Ward 1973, Bargmann \& Horvitz 1991, Turner et al. 1994b, Tamburri et al. 1996, Krug \& Zimmer 2000a, Vickers 2000). Chemical signals have been found to be of importance in aquatic environments to enable organisms to find food and avoid predators (e.g. Tomba et al. 2001). The main chemoreceptive organs in nematodes are the amphids normally placed in the head region (Coomans \& De Grisse 1981), but the inner labial sensilla have also been shown to detect some attractants, such as $\mathrm{Na}^{+}$and $\mathrm{Cl}^{-}$(Dusenbery 1983).

The often patchy distribution of food resources in soft bottoms is thought to cause an aggregated distribution of nematodes at various scales (Gerlach 1977 , Lee et al. 1977, Ólafsson 1992, Ansari \& Gauns 1996, Fabiano \& Danovaro 1999, Neira et al. 2001). Generally, the food is thought of as an attracting factor in most cases (Gerlach 1977, Lee et al. 1977, Neira et al. 2001), but in some instances it seems as if certain food varieties have a repellent or indifferent effect on some 
communities and species (Lee et al. 1977, Gooday et al. 1996). A repellent effect might have caused the large nematode Trichotheristus sp. in our experiment to avoid the benthic algae treatment altogether. Avoidance or differences in attraction cues were also suggested as the explanatory factors for differences in degree of aggregation between nematodes at 2 deepsea sites in the north-east Atlantic (Rice \& Lambshead 1994). We were surprised that nematodes did not choose to settle in the treatment with pelagic diatoms added. A plausible explanation is that the nematodes from our shallow station are much more used to in situ primary producers, such as the one we used in the benthic algae treatment. We know that nematodes from deeper waters (ca. $30 \mathrm{~m}$ ) in the same region do indeed feed upon one of the most common diatom species in the benthic algae treatment, i.e. Skeletonema costatum (Ólafsson et al. 1999), but there in situ primary production of benthic diatoms must be regarded as implausible. We expected also that nematodes would be found in higher numbers in settling containers with sand than in those without sand. This expectation was not borne out by the results. Perhaps the best explanation for this is in the design of the experiment, i.e. there were overriding effects of the benthic algae treatment and this may mask preference for other treatments.

According to our calculations about $70 \%$ of the nematodes had settled to the bottom within $2 \mathrm{~h}$ and 4 and $25 \%$ were in the upper ( 0 to $75 \mathrm{~cm}$ ) and lower $(75$ to $100 \mathrm{~cm}$ ) water column respectively. Quite a few taxa, including nematodes, seemed to be confined to, or dependent on, bed-load transport in the boundary layer before final settlement (Sherman \& Coull 1980, Hagerman \& Rieger 1981, Jonsson et al. 1991, Commito et al. 1995). The high percentage in the water just above the bottom may indicate that these worms were still trying to find suitable spots to settle.

Butman (1987) considered that settlement of invertebrate larvae, on a large scale, is mainly influenced by passive transport. However, on a smaller scale, larval choice for settling spots has been demonstrated in number of studies both in the laboratory and in the field, under still and running water (e.g. Turner et al. 1994a,b, Boxshall 2000, Browne \& Zimmer 2001). We believe that our results are likely to be applicable in the field when it comes to choice or avoidance on a small scale ( $\mathrm{cm}$ or $\mathrm{m})$. In many habitats, such as intertidal areas, currents oscillate considerably, there being periods of still water in between strong currents. Also wind-driven currents in shallow coastal areas may suspend nematodes quite high up in the water column and drive them eventually into stillwater areas. Such conditions are common where we collected sand and animals in Sandviken. There, quite strong winds often prevail during the day, causing suspension of sediment particles and presumably nematodes, while at night the bay becomes calm and the water still.

Some species in the settling containers were not recorded in the source samples. This calls for some concern, in particular for 2 of the abundant species in the benthic algae treatment, i.e. Cobbia sp. and Microlaimus. There are several possible explanations for this: (1) The nematodes were present in the source but not recorded in the sub-samples. We checked the identities of 100 individuals randomly taken from the 8500 added for each run. On average, we found 127 and 77 individuals of Cobbia and Microlaimus respectively in the benthic algae treatment. In theory we should have found 2 individuals belonging to these groups in each 100-individual sub-sample to obtain the numbers found in the settling jars, and therefore it must be judged as possible that we missed them in our sub-samples from the 3 runs analysed. (2) The nematodes came from the water used to fill the cylinder before the source nematodes were added. They may have lived within the pipes of the water system at the field station and then been flushed into the cylinder. We have often recorded nematodes in such water but always in much lower densities than would explain their presence in the settling jars.

One argument against the second explanation is that the density of these genera in the water-column and in the benthic algae treatment was similar among runs, while one would expect a decrease in numbers with an increasing number of runs if this was an important factor.

Regardless of where some of the nematodes came from, there was a clear choice for the benthic algae treatment, indicating strongly that nematodes are not always passively distributed to the sediment after a journey in the water mass.

Acknowledgements. We thank the personnel at Askö for help and their Director, Björn Ganning, for making facilities available. Thanks are due to Göran Malmberg for invaluable assistance with the image analyses and to Kerstin Ullberg for language corrections. David Thistle commented on an earlier version of the manuscript. Three anonymous referees are also thanked for helpful comments.

\section{LITERATURE CITED}

Alongi DM, Boesch DF, Diaz RJ (1983) Colonization of meiobenthos in oil-contaminated subtidal sands in the lower Chesapeake Bay. Mar Biol 72:325-335

Ansari ZA, Gauns MU (1996) A quantitative analysis of fine scale distribution of intertidal meiofauna in response to food resources. Indian J Mar Sci 25:259-263

Atilla N, Fleeger JW (2000) Meiofaunal colonization of artificial substrates in an estuarine embayment. PSZN I: Mar Ecol 21:69-83 
Austen MC, Warwick RM, Rosado MC (1989) Meiobenthic and macrobenthic community structure along a putative pollution gradient in southern Portugal. Mar Pollut Bull 20:398-405

Bargmann CI, Horvitz HR (1991) Chemosensory neurons with overlapping functions direct chemotaxis to multiple chemicals in C. elegans. Neuron 7:729-742

Bell SS, Sherman KM (1980) A field investigation of meiofaunal dispersal: tidal resuspension and implications. Mar Ecol Prog Ser 3:245-249

Bertelsen RD (1997) Active and passive settling by marine benthic nematodes. Old Dominion Univ, University Microfilms Int, Ann Arbor, MI

Billheimer LE, Coull BC (1988) Bioturbation and recolonization of meiobenthos in juvenile Spot (Pisces) feeding pits. Estuar Coast Shelf Sci 27:335-340

Bologna PAX, Heck KL Jr (2000) Impacts of seagrass habitat architecture on bivalve settlement. Estuaries 23:449-457

Boxshall AJ (2000) The importance of flow and settlement cues to larvae of the abalone, Haliotis rufescens Swainson. J Exp Mar Biol Ecol 254:143-167

Browne KA, Zimmer RK (2001) Controlled field release of a waterborne chemical signal stimulates planktonic larvae to settle. Biol Bull 200:87-91

Butman CA (1987) Larval settlement of soft-sediment invertebrates: the spatial scales of pattern explained by active habitat selection and the emerging rôle of hydrodynamical processes. Oceanogr Mar Biol Annu Rev 25:113-165

Chandler GT, Fleeger JW (1983) Meiofaunal colonization of azoic estuarine sediment in Louisiana: mechanisms of dispersal. J Exp Mar Biol Ecol 69:175-188

Chandrasekara WU, Frid CLJ (1996) The effects of relic fauna on initial patch colonisation in a British saltmarsh. Neth J Aquat Ecol 30:49-60

Clarke B (1993) Lecture notes for a training workshop on multivariate analysis of benthic community data. Kristineberg Marine Research Station, 12-14 February 1993, Plymouth Marine Laboratory (in association with the Swedish Environment Protection Board and the University of Oslo), Plymouth

Clarke KR, Green RH (1988) Statistical design and analysis for a 'biological effects' study. Mar Ecol Prog Ser 46: $213-226$

Commito JA, Tita G (2002) Differential dispersal rates in an intertidal meiofauna assemblage. J Exp Mar Biol Ecol 268: $237-256$

Commito J, Thrush S, Pridmore R, Hewitt J, Cummings V (1995) Dispersal dynamics in a wind-driven benthic system. Limnol Oceanogr 40:1513-1518

Coomans A, De Grisse A (1981) Sensory structure. In: Zuckerman BM, Rodhe R (eds) Plant parasitic nematodes, Vol 3. Academic Press, New York, p 127-174

Crofton HD (1966) Nematodes. Hutchinson University Library, London

Dusenbery DB (1983) Chemotactic behavior of nematodes. J Nematol 15:168-173

Fabiano M, Danovaro R (1999) Meiofauna distribution and mesoscale variability in two sites of the Ross Sea (Antarctica) with contrasting food supply. Polar Biol 22:115-123

Fegley SR (1985) Experimental studies on the erosion of meiofauna from soft-substrates by currents and waves. Univ of N Carolina at Chapel Hill, University Microfilms Int, Ann Arbor, MI

Fegley SR (1987) Experimental variation of near-bottom current speeds and its effects on depth distribution of sand-living meiofauna. Mar Biol 95:183-191

Feller RJ, Warwick RM (1988) Energetics. In: Higgins R, Thiel
$\mathrm{H}$ (eds) Introduction to the study of meiofauna. Smithsonian Institution Press, Washington, DC, p 181-196

Gerlach SA (1948) Die Nematodenbesiedlung des Sandstrandes in der Kieler Bucht. Verh Dt Zool Ges Kiel 42:156-165

Gerlach SA (1957) Die Nematodenfauna des Sandstrandes an der Küste von Mittelbrasilien (Brasilianische MeeresNematoden IV). Mitt Zool Mus Berl 33:411-459

Gerlach SA (1977) Attraction to decaying organisms as a possible cause for patchy distribution of nematodes in a Bermuda beach. Ophelia 16:151-165

Gooday AJ, Pfannkuche O, Lambshead PJD (1996) An apparent lack of response by metazoan meiofauna to phytodetritus deposition in the bathyal north-eastern Atlantic. J Mar Biol Assoc UK 76:297-310

Hagerman GM Jr, Rieger RM (1981) Dispersal of benthic meiofauna by wave and current action in Bogue Sound, North Carolina, USA. PSZN I: Mar Ecol 2:245-270

Harvey JG, Vincent CE (1977) Observations of shear in nearbed currents in the southern North Sea. Estuar Coast Mar Sci 5:715-731

Heip C, Vincx M, Vranken G (1985) The ecology of marine nematodes. Oceanogr Mar Biol Annu Rev 23:399-489

Hogue EW (1982) Sediment disturbance and the spatial distributions of shallow water meiobenthic nematodes on the open Oregon coast. J Mar Res 40:551-573

Hogue EW, Miller CB (1981) Effects of sediment microtopography on small-scale spatial distributions of meiobenthic nematodes. J Exp Mar Biol Ecol 53:181-191

Jensen P (1981) Phyto-chemical sensitivity and swimming behaviour of the free-living marine nematode Chromadorita tenuis. Mar Ecol Prog Ser 4:203-206

Jonsson PR, André C, Lindegarth M (1991) Swimming behaviour of marine bivalve larvae in a flume boundary-layer flow: evidence for near-bottom confinement. Mar Ecol Prog Ser 79:67-76

Kern JC, Taghon GL (1986) Can passive recruitment explain harpacticoid copepod distributions in relation to epibenthic structure? J Exp Mar Biol Ecol 101:1-23

Krug PJ, Zimmer RK (2000a) Developmental dimorphism and expression of chemosensory-mediated behavior: habitat selection by a specialist marine herbivore. J Exp Biol 203: 1741-1754

Krug PJ, Zimmer RK (2000b) Larval settlement: chemical markers for tracing production, transport, and distribution of a waterborne cue. Mar Ecol Prog Ser 207:283-296

Lee J, Tietjen J, Mastropaolo C, Rubin H (1977) Food quality and the heterogeneous spatial distribution of meiofauna. Helgol Wiss Meeresunters 30:272-282

Neira C, Sellanes J, Levin LA, Arntz WE (2001) Meiofaunal distributions on the Peru margin: relationship to oxygen and organic matter availability. Deep-Sea Res 48A:2453-2472

Ólafsson E (1992) Small-scale spatial distribution of marine meiobenthos: the effects of decaying macrofauna. Oecologia 90:37-42

Ólafsson E, Moore CG (1990) Control of meiobenthic abundance by macroepifauna in a subtidal muddy habitat. Mar Ecol Prog Ser 65:241-249

Ólafsson E, Moore CG (1992) Effects of macroepifauna on developing nematode and harpacticoid assemblages in a subtidal muddy habitat. Mar Ecol Prog Ser 84:161-171

Ólafsson E, Modig H, van de Bund WJ (1999) Species specific uptake of radio-labelled phytodetritus by benthic meiofauna from the Baltic Sea. Mar Ecol Prog Ser 177:63-72

Olivier F, Tremblay R, Bourget E, Rittschof D (2000) Barnacle settlement: field experiments on the influence of larval supply, tidal level, biofilm quality and age on Balanus amphitrite cyprids. Mar Ecol Prog Ser 199:185-204 
Palmer MA (1983) The role of behavior and flow in the dispersal of marine meiofauna. Dissertation, University of South Carolina, Columbia

Palmer MA (1984) Invertebrate drift: behavioural experiments with intertidal meiobenthos. Mar Behav Physiol 10: 235-253

Peters BG (1928) On the bionomics of the Vinegar eelworm. J Helminthol 6:1-38

Powers SP (1998) Recruitment of soft-bottom benthos (benthic invertebrates, encrusting community, infaunal community). Dissertation, Texas A\&M University, Austin

Rice AL, Lambshead PJD (1994) Patch dynamics in the deepsea benthos: the role of a heterogeneous supply of organic matter. In: Giller PS, Hildrew AG, Raffaelli DG (eds) Aquatic ecology: scale, pattern and process. Blackwell Scientific Publications, London, p 469-497

Riemann F (1988) Nematoda. In: Higgins R, Thiel H (eds) Introduction to the study of meiofauna. The Smithsonian Institution Press, Washington, DC, p 293-301

Savidge WB, Taghon GL (1988) Passive and active components of colonization following two types of disturbance on intertidal sandflat. J Exp Mar Biol Ecol 115: $137-155$

Scheffé H (1953) A method for judging all contrasts in the analysis of variance. Biometrika 40:87-104

Sherman KM, Coull BC (1980) The response of meiofauna to sediment disturbance. J Exp Mar Biol Ecol 46:59-71

Sherman KM, Reidenauer JA, Thistle D, Meeter D (1983) Role of natural disturbance in an assemblage of marine freeliving nematodes. Mar Ecol Prog Ser 11:23-30

Tamburri MN, Finelli CM, Wethey DS, Zimmer-Faust RK (1996) Chemical induction of larval settlement behavior in flow. Biol Bull 191:367-373

Thistle D (1980) The response of a harpacticoid copepod community to a small scale natural disturbance. J Mar Res 38: 381-395

Thistle D, Sherman KM (1985) The nematode fauna of a deepsea site exposed to strong near-bottom currents. Deep-Sea Res 32A:1077-1088

Editorial responsibility: Otto Kinne (Editor),

Oldendorf/Luhe, Germany
Tietjen JH (1976) Distribution and species diversity of deepsea nematodes off North Carolina. Deep-Sea Res 23A: $755-768$

Tietjen JH, Lee JJ (1977) Life histories of marine nematodes. Influence of temperature and salinity on the reproductive potential of Cromadorina germanica Bütschli. Mikrofauna Meeresbod 61:263-270

Tomba AM, Keller TA, Moore PA (2001) Foraging in complex odor landscapes: chemical orientation strategies during stimulation by conflicting chemical cues. J N Am Benthol Soc 20:211-222

Turner EJ, Palmer MA, Luckenbach M, Zimmer-Faust RK (1994a) Settlement of Crassostrea virginica larvae: effects of water flow and a water-soluble chemical cue. J Shellfish Res 13:282

Turner EJ, Zimmer-Faust RK, Palmer MA, Luckenbach M, Pentcheff ND (1994b) Settlement of oyster (Crassostrea virginica) larvae: effects of water flow and a water-soluble chemical cue. Limnol Oceanogr 39:1579-1593

Vickers NJ (2000) Mechanisms of animal navigation in odor plumes. Biol Bull 198:203-212

Wallace HR, Doncaster CC (1964) A comparative study of the movement of some microphagous, plant-parasitic and animal-parasitic nematodes. Parasitology 54:313-326

Ward S (1973) Chemotaxis by the nematode Caenorhabditis elegans: identification of attractants and analysis of the response by use of mutants. Proc Natl Acad Sci USA 70: $817-821$

Warwick RM (1971) Nematode associations in the Exe estuary. J Mar Biol Assoc UK 51:439-454

Welch BL (1947) The generalization of 'Student's' problem when several different population variances are involved. Biometrika 34:28-35

Widbom B (1983) Colonization of azoic sediment by sublittoral meiofauna in Gullmar Fjord - Swedish West Coast. Oceanol Acta Vol Spéc, p 213-217

Zhou H (2001) Effects of leaf litter addition on meiofaunal colonization of azoic sediments in a subtropical mangrove in Hong Kong. J Exp Mar Biol Ecol 256:99-121

Submitted: February 7, 2003; Accepted: May 25, 2003

Proofs received from author(s): September 16, 2003 